A RCHIWA, BIBLIOTEKI

I MUZEA KOŚCIELNE 111 (2019)

https://doi.org.10.31743/abmk.2019.111.26

\title{
ZAKON W PRZESTRZENI MIEJSKIEJ I JEGO WPLYW NA MENTALNOŚĆ LUDZI W DAWNEJ POLSCE. ROZWAŻANIA NAD ROZPRAWA WIKTORA SZYMBORSKIEGO, BRACIA Z ULICY FRETA. STUDIA NAD DOMINIKANAMI WARSZAWSKIMI W EPOCE NOWOŻYTNEJ
}

[Recenzja]: Wiktor Szymborski, Bracia z ulicy Freta. Studia nad dominikanami warszawskimi w epoce nowożytnej, Kraków 2018, s. 371.

Praca Wiktora Szymborskiego zatytułowana Bracia z ulicy Freta. Studia nad dominikanami warszawskimi w epoce nowożytnej wpisuje się w niezwykle popularne $\mathrm{w}$ ostatnim czasie badania, zarówno w polskiej, jak i zagranicznej nauce, dotyczące analizy mentalności ludzi w dawnych wiekach ${ }^{1}$. Na tym tle studia nad życiem codziennym, pracą, edukacją, stosunkiem do współbraci i wiernych

* Urszula Kicińska - dr nauk humanistycznych; adiunkt w Instytucie Historii i Archiwistyki Uniwersytetu Pedagogicznego w Krakowie; e-mail: limula@poczta.onet.pl

https://orcid.org/0000-0002-7967-5312

${ }^{1} \mathrm{Na}$ temat mentalności społeczeństwa polskiego istnieje wiele prac, dotyczą one zarówno osób świeckich, jak i duchownych. Warto podać kilka najważniejszych Z. Kuchowicz, Człowiek polskiego baroku, Łódź 1983; S. Kettering, Patrons, Brokers, and Clients in Seventeenth Century France, Oxford 1986; S. Grzybowski, Sarmatyzm, Kraków 1996; A. Karpiński, Zapisy „pobożne” i postawy religijne mieszczanek polskich $w$ świetle testamentów z drugiej połowy XVI i XVII w., w: Tryumfy i porażki. Studia z dziejów kultury polskiej XVI-XVIII w., red. M. Bogucka, Warszawa 1989, s. 203-233; W. Tygielski, Politics of Patronage in Renaissance Poland. Chancellor Jan Zamoyski, his supporters and the political map of Poland, 1572-1605, Warszawa 1990; J. Ronikier, Hetman Adam Sieniawski i jego regimentarze. Studium z historii mentalności szlachty polskiej 1706-1725, Kraków 1992; Studia z dziejów kultury i mentalności czasów nowożytnych, red. K. Matwijowski, B. Rok, Wrocław 1993, B. Rok, Próba określenia mentalności szlachcica XVIII wieku na podstawie pamiętnika Walentego Klichowskiego, „Przegląd Nauk Historycznych”, 5 (2006) nr 1, s. 109-116; S. Fink De Backer, Widowhood in Early Modern Spain: Protectors, Proprietors, and Patrons, Leiden 2010; U. Kicińska, Wzorzec szlachcianki w polskich drukowanych pogrzebowych XVII wieku, Warszawa 2013; The politics of female households: ladies-in-waiting across early modern Europe, eds. N. Akkerman, B. Houben, Leiden-Boston 2014; Gender and political culture in early modern 
przedstawicieli stanu duchownego, jakim byli warszawscy dominikanie - stanowi istotny wkład w powyższe rozważania, pomimo iż nie są one pionierskie, gdyż próby takie podejmowali już - Bogdan Rok, Tomasz Gałwiaczek, Małgorzata Borkowska, Karolina Targosz czy też Anna Szylar, przy czym w przypadku wspomnianych autorek dotyczyły one w głównej mierze działalności zakonów żeńskich ${ }^{2}$. Ważna pod względem analizowanego zagadnienia jest ponadto kwestia funkcjonowania zakonu w przestrzeni miejskiej, gdyż w średniowieczu, ze względu na monastyczny charakter wielu zgromadzeń, ich siedziby powstawały na obrzeżach miast lub poza nimi. Dopiero zakładane od XIII wieku zakony mendykanckie (np. dominikanie, franciszkanie) jako pierwsze osiedlały się w centrum ośrodków miejskich i z biegiem czasu nabierały coraz większego znaczenia i wpływu na kształt i funkcjonowanie danego obszaru oraz zamieszkujących ich ludzi ${ }^{3}$. Owa współpraca opierała się bowiem nie tylko na licznych donacjach czynionych przez osoby świeckie na rzecz zakonów, lecz także na pomocy, którą poszczególne zgromadzenia niosły społeczności danego terenu, co przejawiało się w ich aktywności charytatywnej, edukacyjnej, społecznej, a nawet politycznej, jeśli weźmiemy pod uwagę działalność wybitnych kaznodziejów, którzy swoją postawą patriotyczną wywarli istotny wpływ na mieszkańców dawnej Polski ${ }^{4}$. Warto ponadto zauważyć, że funkcjonowanie konwentu w konkretnej przestrzeni miejskiej oznaczało zarówno jego działalność gospodarczą, dającą mu samostarczalność, jak i współpracę z dobrodziejami i zacnymi kolatorami poszczególnych zgromadzeń, o czym świadczą epitafia i nagrobki, jakie zachowały się na terenie poszczególnych klasztorów. Poza tym zakonnicy pielęgnowali kult Matki Bożej, Chrystusa, świętych patronów, organizowali konfraternie religijne, głosili kazania, będące specyficznym nośnikiem informacji o religii i otaczającym ich świecie, jak również udzielali sakramentów (p.w. spowiedzi

Europe 1400-1800, eds. J. Daybell, S. Norrhem, London-New York 2017; B. Popiołek, Kobiecy świat w czasach Augusta II. Studia nad mentalnościa kobiet z kręgów szlacheckich, Kraków 2018.

${ }^{2}$ Zob. B. Rok, Mentalność duchowieństwa polskiego w XVIII w., w: Studia z dziejów kultury i mentalności czasów nowożytnych, red. M. Matwijowski, B. Rok, Wrocław 1993, s. 41-55; M. Borkowska, Życie codzienne polskich klasztorów żeńskich w XVII-XVIII wieku, Warszawa 1996; K. Targosz, Piórem zakonnicy. Kronikarki w Polsce XVII w. o swoich zakonach i swoich czasach, Kraków 2002; T. Gałwiaczek, Kształtowanie mentalności chrześcijanina w'sietle kazań dominikańskich czasów saskich, Toruń 2008; A. Szylar, Działalność wychowawczo-edukacyjna żeńskich zgromadzeń zakonnych w Małopolsce w okresie potrydenckim do 1815 roku, Kraków 2012.

${ }^{3}$ Por. I. Sołjan, Sanktuarium jako organizator przestrzeni miejskiej (na przykładzie wybranych sanktuariów w Polsce), „Turyzm” 21 (2011) nr 1-2, s. 50-51; Ł. Myszka, Przestrzeń jako element tożsamości religijnej i przedmiot konfliktów wyznaniowych $w$ czasach nowożytnych na przykładzie dominikanów toruńskich, „Kwartalnik Historii Kultury Materialnej”, 63 (2015) nr 2, s. 341-351.

${ }^{4}$ Zob. M. Brzozowski, Teoria kaznodziejstwa (wiek XVI-XVIII), w: Dzieje teologii katolickiej $w$ Polsce, t. 2: Od odrodzenia do oświecenia, cz. 1: Teologia Humanistyczna, red. Rechowicz, Lublin 1975, s. 361-428; R. Kościelny, Kazania barokowe jako źródło do badań nad mechanizmami ksztattowania postaw mieszkańców Rzeczypospolitej, „Nasza Przeszłość”, 97 (2002) s. 89-124; S. Baczewski, Kazanie pogrzebowe z pierwszej połowy XVII wieku jako spektakl władzy, „Napis”, 12 (2006) s. 275-285; A. Nowicka-Struska, Ex fumo in lucem. Barokowe kaznodziejstwo Andrzeja Kochanowskiego. Lublin 2008. 
i komunii świętej), organizowali nabożeństwa (codzienne i niedzielne) oraz okolicznościowe procesje. Zatem wspomniane powyżej działania, świadczone wobec społeczności danego obszaru, przyciągały wiernych i sprawiały, że konwent stawał się nie tylko „ogniskiem życia religijnego” w danej przestrzeni miejskiej, lecz także w znacznym stopniu, poprzez wyznawane wartości i sposób myślenia, wpływał na kreowanie jej mentalności ${ }^{5}$. W rozważania te $\mathrm{z}$ pewnością można wpisać analizowaną pracę Wiktora Szymborskiego, na podstawie której, poznając środowisko braci dominikanów z ul. Freta, możliwe jest wskazanie wzajemnych więzi, jakie łączyły wspominanych zakonników z innymi duchownymi i osobami świeckimi zamieszkującymi obszar Starej Warszawy.

Ramy czasowe pracy obejmują okres od początku XVII stulecia do wieku XIX. Obszar badawczy zaś zakrojony został do terenów Starej Warszawy, choć to nie zostało przez autora wyraźnie zaznaczone we wstępie. Materiał źródłowy rozprawy obejmuje głównie archiwalia dotyczące dziejów warszawskich dominikanów. Uwaga badacza skupiła się także na analizie legat i testamentów mieszczańskich przechowywanych w zbiorze ksiąg miejskich zarówno Starej, jak i Nowej Warszawy, która jednak nie dała spodziewanych rezultatów, gdyż wyniki tych badań - jak podkreśla autor - „przyniosły dość skromną liczbę zapisów na rzecz konwentu św. Jacka" (s. 9). Stąd też W. Szymborski zdecydował się oprzeć swoje rozważania przede wszystkim na klasztornych rachunkach, gdyż te stanowiąc ,niemalże całkowicie niewykorzystany przez badaczy zbiór, umożliwił przedstawienie szeregu aspektów z życia konwentu, które jak dotąd nie były znane" (s. 10). Sięgając do wspomnianego materiału archiwalnego, W. Szymborski starał się pokazać przeszłość dominikanów w jak najszerszym kontekście, „zarówno pod kątem kwerendy archiwalnej, jak i posługując się metodą komparatystyczną, poprzez zestawienie informacji dotyczących innych konwentów dominikańskich" (s. 10).

Rozprawa składa się z jedenastu części, które nie do końca można uznać za klasyczne rozdziały, gdyż każdy z nich stanowi „niejako odrębną monografię danego zagadnienia" (s.10), w którym została omówiona dana kwestia wraz z wnikliwym przedstawieniem stanu badań we współczesnej nauce, sięgających nie tylko do okresu nowożytności, ale epokę wcześniej, gdyż jak thumaczy autor „nie jest bowiem możliwe zrozumienie mechanizmów rządzących nowożytnym klasztorem bez znajomości korzeni zgromadzenia tkwiącego w wekach średnich" (s. 10). Główne jednak pytanie, które spina niemalże klamrą poszczególne wątki poruszone w pracy, dotyczy społecznego zasięgu oddziaływania konwentu, co starano się wskazać, odtwarzając kulturę intelektualną warszawskich zakonników, ich religijność, wykształcenie, przebieg kariery oraz dokonania dla zakonu oraz ich posługę wobec wiernych i potrzebujących (s. 12).

Pracę otwiera rozdział wstępny zatytułowany Stan badań i postulaty badawcze (s. 15-40), w którym W. Szymborski skoncentrował się przede wszystkim na ukazaniu dziejów warszawskiego konwentu dominikanów, umieszczając go na

${ }^{5}$ Zob. A. Janicka, Kościót i klasztor bernardynów w Radomiu od XV do XVIII w. Miejsce dziatalności społecznej i stały element krajobrazu miejskiego, „Acta Universitatis Lodziensis. Folia Historica", (2010) nr 85, s. 7-20. 
tle ważnych dla stolicy i historii kraju wydarzeń politycznych. Ponadto autor skupił się na przedstawieniu wnikliwej historiografii konwentu dominikańskiego, jak również wskazaniu najważniejszych postulatów badawczych, spośród których podkreślił konieczność „intensyfikacji badań prozopograficznych konwentów dominikańskich w epoce nowożytnej" (s. 25). Istotne, jak zaznaczył badacz, jest także przedstawienie kwestii studiów zagranicznych podejmowanych przez dominikanów, jak również ukazanie miejsca zajmowanego przez stołeczny konwent na tle pozostałych ośrodków. Wspomniane postulaty powinny być ponadto uzupełnione przez wybrane aspekty związane $\mathrm{z}$ historią gospodarczą, szczególnie zaś analizie powinien zostać poddany budżet konwentu, co w znacznym stopniu rozszerzy wiadomości na temat samowystarczalności prowiantowej opisywanego klasztoru. Na opracowanie, jak podkreślił badacz, czeka także funkcjonowanie szkoły wydziałowej znajdującej się przy stołecznym konwencie, której popularność i prestiż wzrosły szczególnie w okresie Królestwa Polskiego. Na uwagę zasługują też zakonne precjoza, naczynia liturgiczne i dzieła sztuki, które w okresie nowożytnym znajdowały się w posiadaniu zakonu, później zaś w dużej mierze uległy rozproszeniu.

W rozdziale drugim noszącym tytuł Początki klasztoru ojców dominikanów $w$ Warszawie (s. 41-80) badacz swoje rozważania oparł na najstarszym znanym inwentarzu klasztoru warszawskiego, pochodzącym z 1612 roku, który składa się z trzech części i tematycznie podzielony został na wykaz parametrów liturgicznych, wot i relikwiarzy (Officina Sacristiae), wykaz książek (Officina Librariae) oraz inwentarz sprzętów kuchennych (Officina Culinae). W. Szymborki skoncentrował się przede wszystkim na dwóch pierwszych częściach wspomnianego źródła. Niniejszy rozdział oparty został zatem na materiale archiwalnym, jakim jest inwentarz, i jemu też autor poświęcił najwięcej uwagi, podkreślając, że „rola staropolskich inwentarzy dla poznania przeszłości jest nie do przeceniania" (s. 42). Są one bowiem wykorzystywane do badania kultury materialnej, historii mentalności, jak również zagadnień związanych z mikrohistorią ${ }^{6}$.

W rozdziale trzecim zatytułowanym Przeorzy $w$ latach 1604-1864 (s. 81-112) uwaga W. Szymborskiego skoncentrowała sięna ukazaniu postacinajwybitniejszych decydentów warszawskiego konwentu św. Jacka, czego dokonał na podstawie metody prozopograficznej. Autor zwrócił także uwagę na fakt (co podparł bardzo obszerną bibliografią), że dotychczasowe badania opierały się na określeniu lat, kiedy dany zakonnik pełnił funkcję w konwencie, pomijane były natomiast jego dalsze losy. Stąd też dotychczas nie podejmowało się prób ukazania poszczególnych karier zakonnych. Autor rozdział ten poświęcił edycji wykazu przeorów klasztoru św. Jacka w Warszawie (s. 87-112), czego dokonał na podstawie notatek pozostawionych przez wybitnego edytora akt kapituł prowincjonalnych -

${ }^{6}$ Zob. A. Klonder, Wszystka spuścizna w Bogu spoczywającego. Majątek ruchomy zwyktych mieszkańców Elblaga i Gdańska w XVII wieku, Warszawa 2000; D. Główka, Rzeczy gdańskie w ruchomościach duchowieństwa katolickiego Rzeczypospolitej w XVII-XVIII w., „Kwartalnik Historii Kultury Materialnej”, (2001) nr 1-2, s. 95-104; A. Pośpiech, Pułapka oczywistości. Pośmiertne spisy ruchomości szlachty wielkopolskiej z XVII wieku, Warszawa 1992; J. Dumanowski, Świat rzeczy szlachty wielkopolskiej w XVIII wieku, Torun 2006. 
Romana Fabiana Madurę. Warto jednak zaznaczyć, że pomimo iż wspomniana edycja zawiera bardzo cenne informacje na temat poszczególnych decydentów stołecznego klasztoru, brakuje w tym rozdziale analizy wspomnianego materiału archiwalnego. Sama edycja źródła to trochę za mało, wydaje się, że niezwykle ważne byłoby także wskazanie najważniejszych i najbardziej zasłużonych postaci oraz przybliżenie czytelnikowi ich biogramów.

W rozdziale czwartym - Pierwsze moderatorium warszawskiego studium generalnego (s. 113-131) - uwaga autora skoncentrowała się na dziejach szkolnictwa zakonnego, na czele którego stało tzw. moderatorium, które tworzyło grono profesorskie danego kolegium, złożone z trzech osób - regensa, bakałarza studium i magistra studentium. Podstawą do opracowania niniejszego rozdziału stało się źródło zatytułowane Liber studii, zawierające wykaz zarówno mistrzów nauczających, jak i studentów biorących udział w wykładach.

Dociekania w rozdziale piątym noszącym tytuł Dobrodzieje warszawskiej biblioteki dominikańskiej (s. 133-156) zostały poświęcone omówieniu znaczenia dawnych księgozbiorów zakonnych dla poznania kultury intelektualnej minionych epok, ze szczególnym naciskiem na konwent św. Jacka. Autor skupił się przede wszystkim na dziejach klasztornej biblioteki, jak również sylwetkach jej dobrodziejów od chwili założenia konwentu aż po czasy napoleońskie. W. Szymborski wskazał ponadto jednego z najwybitniejszych twórców wspomnianego księgozbioru - pierwszego prowincjała warszawskiego zgromadzenia - Wojciecha Sękowskiego, którego działalności poświęcił kilka akapitów (s. 139-142). Uzupełnienie podjętych w tym rozdziale rozważań stanową trzy tabele traktujące o zakupie książek w latach 1668-1817 (tabela nr 1, s. 150-151); ich oprawie i renowacji (tabela $\mathrm{nr} 2$, s. 151-155) oraz wydatkach związanych z funkcjonowaniem czytelni (tabela $\mathrm{nr}$ 3, s. 155-156).

W rozdziale szóstym zatytułowanym Pielgrzymka bractwa różańcowego z Warszawydo Częstochowyw 1608r. (s. 157-175)W. Szymborski swojerozważania poświęcił na syntetyczne przedstawienie działalności bractwa różańcowego przy stołecznym konwencie św. Jacka. Swoją analizę Badacz oparł o cenne źródło, jakim jest Annales Conventus Varsaviensis Ordinis Praedecatorum, w którym znalazł się opis pielgrzymki członków wspomnianego bractwa na Jasną Górę na początku XVII wieku. Fragment ten, jak podkreśla W. Szymborski, posłużył mu do prześledzenia nie tylko dziejów konfraterni, lecz także karier osób bezpośrednio zaangażowanych $\mathrm{w}$ powstanie $\mathrm{i}$ jej bieżącą działalność. Bractwo różańcowe rozpoczęło swoje funkcjonowanie $\mathrm{w}$ dniu 3 listopada 1603 roku, a interesująca autora pielgrzymka odbyła się na wiosnę 1608 roku i została podjęta w intencji ustania zarazy, która szerzyła się wówczas w Rzeczypospolitej. Badacz słusznie wskazuje na epidemię czarnej śmierci (dżumy), która pojawiła się w Warszawie już w 1598 roku i trwała aż do 1606 roku (s. 162), i w jej kontekście podkreśla orędownictwo świętych patronów i Matki Bożej w chwilach zagrożenia, jednakże tej ostatniej - w moim odczuciu - poświęca zbyt mało miejsca, zważywszy na niezwykłą rolę Maryi jako orędowniczki i pocieszycielki w ciężkich dla człowieka chwilach. Na uwagę zasługuje także pozycja i znaczenie Jasnej Góry na tle innych polskich sanktuariów maryjnych, czego niestety autor nie wyjaśnił, 
a także nie wskazał ważniejszych pozycji bibliograficznych na ten temat. Rozdział wieńczy aneks zawierający wykaz członków bractwa różańcowego, działającego przy warszawskim konwencie dominikanów od chwili jego powstania do 1609 roku (s.172-175).

Rozdział siódmy, zdecydowanie najciekawszy, zatytułowany - Dominikanie wobec chorych wspótbraci (s. 177-199) - podejmuje bardzo interesujące rozważania dotyczące opieki medycznej w dawnych klasztorach mendykanckich, które oparto przede wszystkim o analizę rachunków klasztornych od 1603 roku do przełomowych czasów Księstwa Warszawskiego oraz obecności wojsk napoleońskich w Warszawie. Wspomniane źródła uzupełnione zostały o rozporządzenia kapituł generalnych, które normowały kwestie korzystania z opieki medycznej przez zakonników. Na podstawie przytoczonego materiału archiwalnego W. Szymborski wskazał, że pomimo wielu ograniczeń i prawnych zakazów liczba ojców trudniących się medycyną była znaczna. Za ciekawe należy uznać także zagadnienie związane z opieką społeczną, jaką wykazywali zakonnicy wobec swoich współbraci, jak i osób związanych z warszawskim konwentem. Szkoda jednak, że wątek ten nie został rozwinięty, gdyż stanowi on kluczowe zagadnienie pozwalające zrozumieć charakter działalności dobroczynnej i opiekuńczej badanego zakonu. Na uwagę i uznanie zasługuje natomiast analiza dokonana przez autora, w której porównał ceny zabiegów medycznych z różnymi wykonywanymi w tym czasie pracami i otrzymywanymi za nie wynagrodzeniami czy też wprowadzoną $\mathrm{w}$ treść rozdziału, zapewne dla porównania, wartością danych przedmiotów lub zwierząt. Na tym tle, jak wywnioskował W. Szymborski, cena za wykonane zabiegi medyczne nie była zbyt wygórowana, biorąc pod uwagę „kwalifikacje, jakie należało posiadać, aby móc wykonać choćby najprostsze zabiegi chirurgiczne" (s. 198) ${ }^{7}$.

W kolejnym z rozdziałów noszącym tytuł Dominikanie wobec warszawskich żebraków (s. 201-214) uwaga autora skupiła się na przedstawieniu zagadnienia działalności charytatywnej braci kaznodziejów, jednakże nie wobec zakonników, jak to już niejednokrotnie opisywano $\mathrm{w}$ literaturze, ale na jałmużnictwie dokonywanym przez dominikanów wobec mieszkańców Starej Warszawy, co W. Szymborski wymownie nazwał „działaniem żebraków na rzecz żebraków” (s. 205). Pomoc udzielana była ludziom ubogim, wśród których znaleźli się nie tylko lokalni nędzarze, lecz także podróżnicy, inni zakonnicy, pątnicy, ubodzy studenci, żołnierze oraz neofici. Czasem, jak wskazują analizowane przez W. Szymborskiego rachunki, wśród osób proszących o pomoc, pojawiały się także osoby ze szlacheckim rodowodem (tworzące niejednokrotnie tzw. kategorię ubogich wstydliwych) (s. 212) czy też świecki kler. Wskazana działalność wpisywała się, jak podkreślił badacz, w szeroko pojmowane akta miłosierdzia.

Rozdział dziewiąty - Dominikańscy dzierżawcy (s. 215-242) - został poświęcony obecności sfery profanum w sakralnej przestrzeni nowożytnego klasztoru. Celem autora było określenie przejawów przenikania wspomnianej

${ }^{7}$ Zob. K. Błoch, Higiena $w$ klasztorach $w$ świetle wybranych źródel pisanych materialnych $i$ ikonograficznych, w: Czystość i brud. Higiena nowożytna (XV-XVIII w.), red. W. Korpalska, W. Ślusarczyk, Bydgoszcz 2015, s. 42-44. 
sfery profanum do wnętrza klasztoru poprzez przyjmowanie do niego różnorakich gości, jednakże jak podkreślił, nie byli nimi pobożni pielgrzymi czy też wędrujący zakonnicy. Główne rozważania autora skupiły się na tym, by prześledzić motywację, która „skłoniła osoby świeckie i duchowne do wynajęcia pomieszczenia w warszawskim" konwencie (s. 221), jak również na wskazaniu, kto zazwyczaj korzystał z tego typu wynajmu. W rozdziale tym W. Szymborski pominął niestety niezwykle ważne zagadnienie, jakim byli świeccy rezydenci klasztornych cel, którzy decydowali się na zamieszkanie w tym miejscu zazwyczaj w sytuacji przewlekłej, nieuleczalnej choroby, bądź starości.

Przedostatni rozdział noszący tytuł Dieta dominikańska (s. 243-259), został poświęcony zagadnieniu aprowizacji w stołecznym zakonie braci kaznodziejów. Badacz po raz kolejny analizując klasztorne rachunki, a także zapisy normatywne, znajdujące się $\mathrm{w}$ aktach kapituł generalnych, skoncentrował się przede wszystkim na wskazaniu zakonnego menu, które jak wywnioskował, w dużej mierze opierało się na trendach nowożytnej medycyny, gdyż dla chorych nabywano lepszą gatunkowo żywność, bardziej kaloryczną i taką, która wówczas była uważana za leczniczą. Rozdział kończy edycja spisu sprzętów kuchennych znajdujących się w konwencie warszawskim z około 1610 roku (aneks 1, s. 259). Wydaje się jednak, że w rozdziale tym brakuje szerszego ukazania zagadnienia codziennej diety klasztornej i porównania jej z sytuacją, kiedy towary były sprowadzane i przeznaczane na użytek osób leczących się w omawianym konwencie, jak również tych, które przyrządzane były z okazji obchodzonych przez braci świąt czy też okolicznościowych uroczystości, związanych ze wspomnieniem danego patrona. Tego typu porównanie pozwoliłoby na wyciągnięcie wniosku dotyczącego stanu i poziomu kuchni dominikańskiej ${ }^{8}$.

Rozdział ostatni, jedenasty, noszący tytuł Dominikanie $i$ opieka nad zwierzętami (s. 261-274) został poświęcony trosce, jaką zakonnicy roztaczali nad końmi, owcami, bydłem, psami czy też trzodą chlewną, badacz wskazał metody ich leczenia i skonstatował, że wiedza, którą posiadali tzw. konowałowie, pochodziła głównie ze staropolskich kalendarzy, w których szeroko opisywane były kwestie medyczne, rolnicze i zootechniczne.

Pracę wieńczy syntetyczne podsumowanie w języku polskim (s. 275-280) oraz angielskim (s. 281-286), w którym autor oprócz wskazania ogólnych wniosków, wynikających z treści poszczególnych rozdziałów, podkreślił, że przygotowując omówione powyżej szkice, starał się przede wszystkim „uwzględnić najpilniejsze postulaty badawcze, takie jak edycja źródeł oraz studia prozpograficzne” (s. 275), gdyż tylko dzięki nim możliwe jest uzyskanie najpełniejszego obrazu działalności społecznej stołecznych dominikanów w epoce nowożytnej. Uzupełnieniem rozważań jest bardzo obszerna bibliografia, podzielona na materiały archiwalne rękopiśmienne (s. 287-296) i drukowane (s. 297-302) oraz opracowania (s. 303-351).

${ }^{8}$ Por. J. Szpak, W szatni, kuchni i światyni klasztornej. Środki oddziaływania na sensualność wiernych w placówkach prowadzonych przez zakon paulinów, w: Staropolski ogląd świata. Sarmacki sensualizm, red. F. Wolański, Toruń 2017, s. 81-82; B. Manyś, Smaki i gusta kulinarne w sarmackiej kuchni wileńskich zakonników w dobie saskiej, w: Staropolski ogląd świata, s. 219-230. 
Rozprawa Wiktora Szymborskiego zatytułowana Bracia z ulicy Freta. Studia nad dominikanami warszawskimi w epoce nowożytnej ze względu na swój interdyscyplinarny charakter z powodzeniem wpisuje się w bardzo ważne i popularne w ostatnim czasie rozważania nad mentalnością ludzi w dawnej Polsce, interpretowane pod kątem historycznym, antropologicznym i mentalnościowym. Praca ta, pomimo iż stanowi zbiór artykułów na temat funkcjonowania konwentów dominikanów w Starej Warszawie, tworzy znakomitą, wielowątkową syntezę. Każdy z artykułów wymagał bowiem od autora ogromnego nakładu pracy, a śledzenie i czasem żmudne analizowanie rachunków klasztornych pozwoliło znaleźć odpowiedź na wiele nurtujących pytań dotyczących życia codziennego, edukacji, lecznictwa czy też działalności gospodarczej konwentu św. Jacka, co $\mathrm{w}$ znacznym stopniu zapełniło niszę istniejącą na ten temat w dotychczasowych badaniach nad kwestią zakonów, jak i obrazu społeczeństwa baroku, w który bez wątpienia wpisywały się osoby duchowne, odgrywając $\mathrm{w}$ nim istotną rolę. $\mathrm{O}$ profesjonalizmie autora świadczy również bardzo obszerna bibliografia, zawierająca bazę źródłową i literaturę przedmiotu. Na szczególną pochwałę zasługuje zaś rozdział dotyczący posługi dominikanów względem chorych współbraci, jak i potrzebujących mieszkańców stolicy i całej rzeszy żebraków, którzy w stołecznym klasztorze konwentu św. Jacka szukali schronienia i pocieszenia $\mathrm{w}$ trudnych momentach życia.

Znakomicie przygotowane studium nie jest jednak wolne od kilku niedociągnięć. We wstępie nie została wyraźnie zaznaczona rama czasowa pracy, autor wspomina wprawdzie o badaniach prowadzonych na przestrzeni XVII-XIX wieku (epoka napoleońska), gdyż z tego okresu pochodzą analizowane rachunki klasztorne, jednak wybór ten nie został wnikliwie uzasadniony. Rozszerzenia i uzupełnienia wymagałby także fragment dotyczący klasztornych dobrodziejów (zarówno świeckich, jak i duchownych), gdyż nie zostali oni dokładnie i wyczerpująco przedstawieni. Zwrócić należy także uwagę na zagadnienia podjęte przez autora $\mathrm{w}$ rozdziale drugim, gdzie wspomina o roli inwentarza $\mathrm{w}$ badaniu dziejów konwentu św. Jacka, jak również jego przydatności do analizy mentalności ludzi $\mathrm{w}$ dawnej Polsce. Wydaje się, że zagadnienie to zostało potraktowane zbyt skrótowo, pomimo iż autor wyraźnie zaznacza, że źródło to interesuje go jedynie pod kątem historii Kościoła, co podpiera odpowiednio obszerną literaturą. Zamieszone na końcu rozdziału piątego trzy tabele dotyczące dziejów księgozbioru w klasztornej bibliotece (s. 150-156) bezapelacyjnie wymagały od badacza bardzo dużo czasu na etapie ich przygotowania. Brak jednakże ich analizy oraz odpowiedniego merytorycznego komentarza, niewiele wnoszą w treść rozdziału. $\mathrm{W}$ rozdziale szóstym zaś brakuje informacji na temat tego, jak działalność bractwa religijnego, a w tym wypadku różańcowego, wpływała na mieszkańców stolicy oraz jakie było jej społeczne i religijne odziaływanie? Ponadto warto było przy jego konstrukcji wskazać ważniejsze postaci świeckie, należące do wspomnianej konfraterni, czy też jej darczyńców. Uwaga pojawia się także po lekturze rozdziału dziesiątego, który wieńczy edycja spisu sprzętów kuchennych, znajdujących się w konwencie warszawskich dominikanów, pochodzącego z około 1610 roku (aneks 1, s. 259). Po raz kolejny autor tłumaczy, że podczas edycji 
źródła opierał się na instrukcji Kazimierza Lepszego ${ }^{9}$, co jest raczej wyrazem jego nadgorliwości, gdyż jednorazowe wyjaśnienie zasad edytorskich jest w pełni wystraczające. Ponadto ponowny brak analizy w tekście głównym wspomnianego materiału archiwalnego powoduje, że czytelnik nie do końca rozumie zasadność wprowadzenia tego źródła do treści rozdziału. Na koniec warto nadmienić, że w rozdziale jedenastym autor skupia się na opiece i metodach leczenia zwierząt, jednakże po lekturze tego fragmentu odnosi się wrażenie, że koncertuje się on wyłącznie na leczeniu koni.

Na koniec warto podnieść jeszcze jedną kwestię. Otóż w tego typu badaniach, kiedy zależy nam na wskazaniu określonego zachowania, wyznawanych wartości oraz sposobu myślenia danej grupy społecznej, warto sięgnąc do kilku rodzajów źródeł - korespondencji, kronik zakonnych, modlitewników, relacji, poezji klasztornej. Szczególnie cenna może okazać się korespondencja, która pozwoli prześledzić rodzaj i zasięg współpracy członków danego zgromadzenia, a w tym wypadku stołecznych dominikanów, $\mathrm{z}$ rodziną, krewnymi, opiekunami oraz kolatorami, dokonującymi różnorakich donacji na rzecz klasztoru i Kościoła. Wspomniane źródła pomogłyby także wskazać inne bardzo cenne informacje dotyczące wartości wyznawanych przez duchownych, do których, oprócz pobożności, religijności, bogobojności, wytrwałości, gorliwości religijnej, zaliczyć można stosunek duchownych do Boga, Matki Bożej i świętych patronów. Ważne byłoby także szersze określenie wartości wspólnych dominikanów, czyli ich stosunku do ojczyzny, narodu i władcy czy też wartości indywidualnych, wśród których za najbardziej istotne należy uznać zdrowie, ród (z którego się wywodzili) oraz stosunek do reguły zakonnej i jej wpływu na przebieg kariery poszczególnych duchownych. Za równie ważne, jak powyższe, należy uznać ponadto wartości uniwersalne, czyli dobro, prawdę, piękno, sprawiedliwość czy też stosunek do śmierci ${ }^{10}$. Szczególnie ostatnia $\mathrm{z}$ wymienionych wartości zasługuje na dogłębną analizę, gdyż obejmowała ona znaczny obszar działania i funkcjonowania ludzi w dawnych wiekach, zarówno duchownych, jak i świeckich. Ugruntowany bowiem w nowożytnej świadomości pogląd uznający życie za ziemską wędrówkę, w której człowiek jako tzw. homo viator zmierza do śmierci, determinowało zachowanie ludzi w ciągu całego życia, na co wpływ miały poradniki dobrego życia i umierania ${ }^{11}$.

${ }^{9}$ Zob. K. Lepszy, Instrukcja wydawnicza dla źródeł historycznych. Od XVI do połowy XIX wieku, Wrocław 1953 [autor zapewne omyłkowo wskazuje tytuł instrukcji w następujący sposób: Instrukcja wydawnicza do źródeł historycznych od XVI do poł. XIX w. (np. s. 51, s. 67)].

${ }^{10}$ Por. B. Popiołek, ,, W wielkim strachu i bojaźni rezydujem... ”. Mentalność zakonnic w okresie saskim. Próba sondażu, [w:] Klasztory mnisze na wschodnich terenach dawnej Rzeczypospolitej od XVI do początków XX wieku, red. J. Gwioździk, R. Witkowski, A.M. Wyrwa, Poznań 2014, s. 187188; B. Popiołek, Kobiecy świat w czasach Augusta II (szczególnie wstęp).

${ }^{11} \mathrm{Na}$ ten temat zob. M. Włodarski, Ars moriendi w literaturze polskiej XV i XVI w., Kraków 1987; A. Wieczorkiewicz, Drogi życia i drogi poznania. Alegoryczne wizje wędrówki w literaturze dawnej, „Pamiętnik Literacki”, R. 84:1993, z. 2, s. 3-28; B. Rok, Zagadnienie śmierci w czasach nowożytnych - próba postanowienie problematyki badawczej $i$ charakterystyka źródet, „Medycyna Nowożytna. Studia nad Historią Medycyny”, 1 (1994) nr 1, s. 23-46; B. Rok, Człowiek wobec śmier- 
Zaprezentowane powyżej uwagi nie umniejszają jednak wartości pracy, która stanowi znakomitą syntezę antropologiczno-mentalnościową niezwykle potrzebną we współczesnej nauce. Badania te, szczególnie w przypadku dziejów i funkcjonowania klasztorów w przestrzeni miejskiej, wypełniają dotychczasową lukę i zachęcają do podejmowania dalszych interdyscyplinarnych studiów łączących ze sobązagadnienia historyczne z kulturotwórczymi, antropologicznymi, gospodarczymi czy też prawnymi.

\section{BIBLIOGRAFIA}

Baczewski Sławomir, Kazanie pogrzebowe z pierwszej polowy XVII wieku jako spektakl wtadzy, „Napis”, 12 (2006) s. 275-285.

Błoch Katarzyna, Higiena w klasztorach wświetle wybranych źródet pisanych materialnych $i$ ikonograficznych, w: Czystość i brud. Higiena nowożytna (XV-XVIII w.), red. W. Korpalska, W. Ślusarczyk, Bydgoszcz 2015, s. 42-44.

Borkowska Małgorzata, Życie codzienne polskich klasztorów żeńskich w XVII-XVIII wieku, Warszawa 1996.

Brzozowski Mieczysław, Teoria kaznodziejstwa (wiek XVI-XVIII), w: Dzieje teologii katolickiej w Polsce, t. 2: Ododrodzenia do oświecenia, cz. 1: Teologia Humanistyczna, red. M. Rechowicz, Lublin 1975, s. 361-428.

Dumanowski Jarosław, Świat rzeczy szlachty wielkopolskiej w XVIII wieku, Torun 2006.

Fink De Backer Stephanie, Widowhood in Early Modern Spain: Protectors, Proprietors, and Patrons, Leiden 2010.

Gałwiaczek Tomasz, Ksztattowanie mentalności chrześcijanina w świetle kazań dominikańskich czasów saskich, Toruń 2008.

Gender and political culture in early modern Europe 1400-1800, ed. J. Daybell, S. Norrhem, London-New York 2017.

Główka Dariusz, Rzeczy gdańskie w ruchomościach duchowieństwa katolickiego Rzeczypospolitej w XVII-XVIII w., „Kwartalnik Historii Kultury Materialnej”, (2001) nr 1-2, s. 95-104.

Grzybowski Stanisław, Sarmatyzm, Kraków 1996.

Janicka Anna, Kościót i klasztor bernardynów w Radomiu od XV do XVIII w. Miejsce działalności spolecznej $i$ stały element krajobrazu miejskiego, „Acta Universitatis Lodziensis. Folia Historica", (2010) nr 85, s. 7-20.

Karpiński Andrzej, Zapisy „pobożne” i postawy religijne mieszczanek polskich w świetle testamentów z drugiej połowy XVI i XVII w., w: Tryumfy i porażki. Studia z dziejów kultury polskiej XVI-XVIII w., red. M. Bogucka, Warszawa 1989, s. 203-233

Kettering Sharon, Patrons, Brokers, and Clients in seventeenth-century France, Oxford 1986.

Kicińska Urszula, Wzorzec szlachcianki w polskich drukowanych pogrzebowych XVII wieku, Warszawa 2013.

ci w kulturze staropolskiej, Wrocław 1995; B. Rok, System wartości moralnych w poradnikach dobrego życia w XVIII wieku, w: Edukacja ku wartościom, red. A. Szeląg, Kraków 2004, s. 227-236; W. Wojtkiewicz-Rok, Problemy zdrowia i choroby w polskich poradnikach dobrego życia $w$ XVIII w., „Medycyna Nowożytna. Studia nad Historią Medycyny”, 3 (1996) z. 1-2, s. 65-73; M. Vovelle, Śmierć w cywilizacji Zachodu. Od roku 1300 po wspótczesność, Gdańsk 2004. 
Klonder Andrzej, Wszystka spuścizna w Bogu spoczywającego. Majątek ruchomy zwyktych mieszkańców Elblaga i Gdańska w XVII wieku, Warszawa 2000.

Kościelny Robert, Kazania barokowe jako źródło do badań nad mechanizmami kształtowania postaw mieszkańców Rzeczypospolitej, „Nasza Przeszłość”, 97 (2002) s. 89-124.

Kuchowicz Zbigniew, Człowiek polskiego baroku, Łódź 1983.

Lepszy Kazimierz, Instrukcja wydawnicza dla źródet historycznych od XVI do połowy XIX wieku, Wrocław 1953.

Manyś Bernadetta, Smaki i gusta kulinarne w sarmackiej kuchni wileńskich zakonników $w$ dobie saskiej, w: Staropolski ogląd świata. Sarmacki sensualizm, red. F. Wolański, Toruń 2017, s. 219-230.

Myszka Łukasz, Przestrzeń jako element tożsamości religijnej i przedmiot konfliktów wyznaniowych $w$ czasach nowożytnych na przykładzie dominikanów toruńskich, „Kwartalnik Historii Kultury Materialnej”, 63 (2015) nr 2, s. 341-351.

Nowicka-Struska Anna, Ex fumo in lucem. Barokowe kaznodziejstwo Andrzeja Kochanowskiego. Lublin 2008.

Popiołek Bożena, „, $W$ wielkim strachu $i$ bojaźni rezydujem...”. Mentalność zakonnic wokresie saskim. Próba sondażu, w: Klasztory mnisze na wschodnich terenach dawnej Rzeczypospolitej od XVI do poczatków XX wieku, red. J. Gwioździk, R. Witkowski, A.M. Wyrwa, Poznań 2014, s. 187-188

Popiołek Bożena, Kobiecy świat w czasach Augusta II. Studia nad mentalnościa kobiet z kręgów szlacheckich, Kraków 2018.

Pośpiech Andrzej, Pułapka oczywistości. Pośmiertne spisy ruchomości szlachty wielkopolskiej z XVII wieku, Warszawa 1992.

Rok Bogdan, Mentalność duchowieństwa polskiego $w$ XVIII w., w: Studia z dziejów kultury i mentalności czasów nowożytnych, red. M. Matwijowski, B. Rok, Wrocław 1993, s. 41-55.

Rok Bogdan, Zagadnienie śmierci $w$ czasach nowożytnych - próba postanowienie problematyki badawczej i charakterystyka źródet, „Medycyna Nowożytna. Studia nad Historią Medycyny", 1 (1994), nr 1, s. 23-46.

Rok Bogdan, Człowiek wobec śmierci w kulturze staropolskiej, Wrocław 1995.

Rok Bogdan, System wartości moralnych w poradnikach dobrego życia $w$ XVIII wieku, w: Edukacja ku wartościom, red. A. Szeląg, Kraków 2004, s. 227-236.

Rok Bogdan, Próba określenia mentalności szlachcica XVIII wieku na podstawie pamiętnika Walentego Klichowskiego, „Przegląd Nauk Historycznych”, 5 (2006) nr 1, s. 109-116.

Ronikier Jerzy, Hetman Adam Sieniawski i jego regimentarze. Studium z historii mentalności szlachty polskiej 1706-1725, Kraków 1992.

Sołjan Izabela, Sanktuarium jako organizator przestrzeni miejskiej (na przykładzie wybranych sanktuariów w Polsce), „Turyzm”, 21 (2011) nr 1-2, s. 50-51.

Szpak Jacek, W szatni, kuchni i światyni klasztornej. Środki oddziaływania na sensualność wiernych $w$ placówkach prowadzonych przez zakon paulinów, w: Staropolski oglad świata. Sarmacki sensualizm, red. F. Wolański, Toruń 2017, s. 81-82.

Studia z dziejów kultury i mentalności czasów nowożytnych, red. K. Matwijowski, B. Rok, Wrocław 1993.

Szylar Anna, Działalność wychowawczo-edukacyjna żeńskich zgromadzeń zakonnych w Małopolsce w okresie potrydenckim do 1815 roku, Kraków 2012.

Targosz Karolina, Piórem zakonnicy. Kronikarki w Polsce XVII w. o swoich zakonach $i$ swoich czasach, Kraków 2002. 
The politics of female households: ladies-in-waiting across early modern Europe, eds. N. Akkerman, B. Houben, Leiden-Boston 2014.

Tygielski Wojciech, Politics of Patronage in Renaissance Poland. Chancellor Jan Zamoyski, his supporters and the political map of Poland, 1572-1605, Warszawa 1990.

Vovelle Michel, Śmierć w cywilizacji Zachodu. Od roku 1300 po wspótczesność, Gdańsk 2004

Wieczorkiewicz Anna, Drogi życia $i$ drogi poznania. Alegoryczne wizje wędrówki w literaturze dawnej, „Pamiętnik Literacki”, 84 (1993) z. 2, s. 3-28.

Włodarski Maciej, Ars moriendi w literaturze polskiej XV i XVI w., Kraków 1987.

Wojtkiewicz-Rok Wanda, Problemy zdrowia $i$ choroby $w$ polskich poradnikach dobrego życia w XVIII w., „Medycyna Nowożytna. Studia nad Historią Medycyny”, 3 (1996) z. 1-2, s. 65-73. 